\title{
PARASITOLOGY
}




\title{
PARAS I TOLOGY
}

(Founded by G. H. F. Nuttall, F.R.S.)

\author{
EDITED B Y \\ D. KEILIN, Sc.D., F.R.S.
}

IN CONJUNCTION WITH
H. A. BAYLIS, M.A., D.Sc.
E. H IN DLE, Ph.D., Sc.D.
F. J. BROWN, M.Sc.
C. A. HOARE, D.Sc.
P. A. BUXTON, M.A., M.R.C.S.
K. M. SMITH, Рн.B., F.R.S.
C. DOBELL, F.R.S.
P. TATE, M.Sc., Рн.D.

W. R. THOMPSON, F.R.S.

VOLUME 32,1940

\author{
Reprinted 1966 for \\ Wm. DAWSON \& SONS LTD., LONDON \\ with the permission of the Proprietors
}


ORIGINALLY PRINTED IN GREAT BRITAIN

BY THE CAMBRIDGE UNIVERSITY PRESS.

REPRINTED IN THE NETHERLANDS BY

KRIPS/OOSTHOEK, MEPPEL AND UTRECHT 


\title{
C O N T E N T S
}

\author{
No. 1 (APRIL)
}

Nuttall, The late G. H. F. Notes on the preparation of papers for publication in the Journal of Hygiene and in Parasitology

PAGE

WebB, J. Lewis and Hervel, J. E. A new record of Plasmodium ovale (Stephens, 1922) . . . . . . . . .

Evans, W. M. R. Observations on the incidence of some nematode parasites of the common rabbit, Oryctolagus cuniculus. (With 5 Figures in the Text) . . . . . . . .

Evans, W. M. R. Observations upon some common cestode parasites of the wild rabbit, Oryctolagus cuniculus. (With 6 Figures in the Text)

Radford, Charles D. Notes on some new species of parasitic mites. Part 3. (With 19 Figures in the Text)

Hoare, Cecrl A. Studies on the behaviour of Trypanosoma evansi in tsetse-flies with special reference to its phylogeny. (With $1 \mathrm{Map}$ )

Dobelt, Clifford, Vilém Lambl (1824-1895). A portrait and a biographical note. (With Plate I)

\section{No. 2 (JUNE)}

JoHnson, C. G. Development, hatching and mortality of the eggs of Cimex lectularius L. (Hemiptera) in relation to climate, with observations on the effects of preconditioning to temperature. (With 13 Figures in the Text)

Baer, Jean G. Some avian tapeworms from Antigua. (With 37 Figures in the Text) .

Davies, Thomas IDwal. Three closely related species of Aploparaksis Clerc, 1903. (With 10 Figures in the Text) . .

Rogers, W. P. The effect of environmental conditions on the accessibility of third stage trichostrongyle larvae to grazing animals. (With 12 Figures in the Text) . . . . .

Hoare, Cecil A. On an Entamoeba occurring in English goats. (With 16 Figures in the Text) 


\section{No. 3 (AUgust)}

Johnson, C. G. The longevity of the fasting bed-bug (C. lectu-

larius L.) under experimental conditions and particularly in relation to the saturation deficiency law of water-loss. (With 11 Figures in the Text) . . . . . . . .

Dawes, Ben. Hexacotyle extensicauda n.sp., a monogenetic trematode from the gills of the tunny (Thunnus thynnus L.). (With 6 Figures in the Text).

Dawes, Ben. Notes on the formation of the egg capsules in the monogenetic trematode, Hexacotyle extensicauda Dawes, 1940. (With 3 Figures in the Text). . . . . . .

Buxton, P. A. Studies on populations of head-lice (Pediculus humanus capitis: Anoplura). III. Material from South India .

Buxron, P. A. The biology of the body louse (Pediculus humanus corporis: Anoplura) under experimental conditions

Carrick, Robert and Bullovgh, W. S. The feeding of the tick, Ixodes recinus $\mathrm{L}$., in relation to the reproductive condition of the host. (With 1 Figure in the Text) . . . . .

Crofton, H. Draper, A note on Microcotyle fusiformis Goto. A fish trematode new to Britain

Smith, Kenneth M. and MacClement, W. D. Filtration studies on Nicotiana virus 11. (With Plate II and 7 Figures in the Text)

Fantham, H. B., Porter, Annie and Richardson, L. R. Some more myxosporidia observed in Canadian fishes. (With Plates III and IV)

\section{No. 4 (November)}

Webb, J. Lewis. The occurrence of Rickettsia-like bodies in the Reduviid bug Triatoma rubrofasciata and their transmission to laboratory animals. (With 1 Figure in the Text) . . .

Bower-Shore, Clifford. An investigation of the common fish louse, Argulus foliaceus (Linn.). (With 1 Figure in the Text) .

Rees, Gwendolen. Studies on the germ cell cycle of the digenetic trematode Parorchis acanthus Nicoll. Part II. Structure of the miracidium and germinal development in the larval stages. (With 42 Figures in the Text) 
RAY, H.N. and DAS-GUPTA, M. Adelina schellacki n.sp., a coccidium from the intestine of the Indian centipede Cormocephalus dentipes Poc. (With Plate V, containing Figs. 1-15) . . 392

Cawston, F. Gordon. Some difficulties in determining the life cycle of Fasciola . . . . . . . . . . . . . . .

Jobling, B. Description of the young female and of the male of Ascodipteron africanum Jobling (Diptera, Streblidae). (With 1 Figure in the Text)

LeA, D. E. and Smith, Kenneth M. The inactivation of plant viruses by radiation. (With 6 Figures in the Text)

Dobell, Clifford. Researches on the intestinal protozoa of monkeys and man. X. The life-history of Dientamoeba fragilis: observations, experiments, and speculations. (With Plates VI and VII and 1 Figure in the Text) . . . . . .

TATE, P. On Mycetosporidium jacksonae n.sp. parasitic in species of Sitona weevils. (With Plates VIII and IX, containing Figs. 1-23

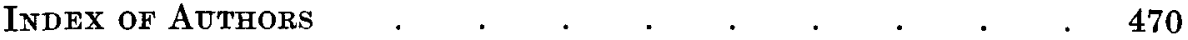

INDEX OF SUBJECTS $\quad . \quad . \quad . \quad . \quad . \quad . \quad . \quad . \quad .472$ 